\title{
Indhold
}

Forord 7

Peter Larsen

Barthes' retorik

Kommentarer til en oversættelse 11

\section{Roland Barthes}

Den gamle retorik

Håndbog 21

Carsten Sestoft

Taktik uden strategi

Barthes i det intellektuelle felt 89

Per Krogh Hansen

Betydningens flossede struktur

Introduktion til Roland Barthes' tekstuelle analyse 117

John Thobo-Carlsen

Om litteratur på tærsklen til en verden uden litteratur

En sammenholdning af Barthes' og Benjamins

syn på forholdet mellem sprog og litteratur 145

Anmeldelser 183

Marianne Alenius, Pil Dahlerup, Søren Peter Hansen, Hans Hertel og Peter Meisling (red.): Digternes paryk. Studier i 1700-tallet. Festskrift til Thomas Bredsdorff (Svend Aage Svenstrup).

Karin Sanders: Konturer. Skulptur- og dødsbilleder fra guldalderlitteraturen (Anne Scott Sørensen) 